\title{
Penerapan E-court Dalam Perkara Tindak \\ Pidana Umum Dalam Prespektif Hukum \\ ProgresiF
}

\author{
Ari Hani Saputri \\ Kejaksaan Negeri Gunungkidul \\ arihanisaputri@yahoo.co.id
}

\begin{abstract}
This article tries to discuss the implementation of e-court in general criminal cases. In fact, Perma Number 1 Year 2019 does not include criminal cases. This is because Perma Number 1 of 2019 only allows general civil, family civil, state administrative, and military administrative matters. However, with the corona virus outbreak making the implementation of criminal cases into an online trial, this has a positive impact in the form of a breakthrough for the litigation world due to the existence of e-court, it can be predicted to decrease costs for the trial, but on the other hand there are weaknesses, namely not yet arranged e court for criminal cases. To find a way out, the authors recommend implementing progressive law to fill the legal vacuum while waiting for a positive law that accommodates the implementation of e-court
\end{abstract}

Keywords: E-court, General Criminal Case, Progressive Law

\begin{abstract}
Abstrak
Artikel ini mencoba untuk membahas mengenai pelaksaan $e$-court dalam perkara pidana umum. Sejatinya, dalam Perma Nomor 1 Tahun 2019 tidak mengikutsertakan perkara pidana. Hal ini dikarenakan Perma Nomor 1 Tahun 2019 hanya memperbolehkan perkara perdata umum, perdata keluarga, tata usaha negara, tata usaha militer. Namun dengan adanya wabah virus korona membuat pelaksaan perkara pidana menjadi sidang secara online, hal ini membawa dampak positif berupa terobosan untuk dunia litigasi dikarenakan dengan adanya $e$-court maka dapat diprediksikan menurunnya biaya untuk persidangan, namun dilain sisi terdapat kelemahan, yaitu belum diaturnya pelaksanaan $e$ court untuk perkara pidana. Untuk mencari jalan keluarnya maka penulis menganjurkan diterapkannya hukum progresif untuk mengisi kekosongan hukum sambil menunggu adanya sebuah hukum positif yang mengakomodasi pelaksanaan $e$-court.
\end{abstract}

Kata Kunci: E-court, Perkara Pidana Umum, Hukum Progresif 


\section{A. PENDAHULUAN}

Virus Korona membawa dampak yang sangat besar kepada kehidupan umat manusia, termasuk dalam system peradilan. Hingga awal April 2020, lebih dari 10 ribu perkara harus diselesaikan melalui sidang online di tengah wabah global covid-19. Namun yang menjadi permasalahan adalah minimnya pengaturan sidang secara online dalam peraturan perundang-undangan di Indonesia.

Persidangan secara online bukanlah hal baru dalam dunia hukum, Federal Civil Justice Reform Act Tahun 1990 akhirnya mereformasi dunia peradilan di Amerika Serikat dengan penerapan digitasi12 pasca invensi chip komputer. ${ }^{1}$ Amerika Serikat telah lebih dulu mengenal Virtual Civil Courts sejak tahun 1998, di mana persidangan telah menggunakan media video conference dan telah mengenal electronic filling dan case management software. ${ }^{2}$ Selanjutnya di Amerika Serikat, berdasarkan House Bill 4140 yang disetujui pada November 2001 dan disahkan sebagai Public Act 262 of 2001

\footnotetext{
${ }^{1}$ Paul D. Carrington, "Virtual Civil Litigation : A Visit to J ohn Bunyan's Celestial City", Columbia Law Review, Vol. 98, No.4, 1990, hlm 1516-1517

${ }^{2}$ Fredric I. Lederer, "The Road to the Virtual Courtroom? A Consideration of Today's - and Tomorrow's- High Technology Courtrooms, Virginia, Faculty Publications" - William and Mary Law School Scholarship Repository, 1999 hlm 800-801
}

HPE. Vol. 8 No.1 Jan-Juni 2020 pada 9 Januari 2002, Para pihak seperti juri, terdakwa, pengacara dan hakim tidak harus berada di dalam ruang persidangan namun bisa menggunakan video conference sebagai media komunikasi dalam proses pemeriksaan persidangan. ${ }^{3}$

Terlepas dari pandemi virus korona, sidang online sudah selayaknya diterapkan secara luas di Indonesia. Hal ini dikarenakan sidang online sesuai dengan asas penyelenggaran yang dituntut untuk sederhana, cepat dan biaya ringan (Vide Pasal 2 ayat (4) Undang-Undang Nomor 48 Tahun 2009 tentang Kekuasaan Kehakiman). Dengan diterapkannya sidang online maka para pihak yang mempunyai kepentingan tidak perlu lagi membuang waktu untuk menunggu giliran kasusnya diperiksa dimuka pengadilan. Sudah bukan rahasia lagi bahwa pengadilan di Indonesia memakan waktu. Namun sayangnya Perma No.1 Tahun 2019 tidak mengakomodasikan perkara pidana, baik pidana umum maupun pidana khusus. Oleh sebab itu dibutuhkan sebuah peraturan yang mengakomodasi perkara pidana. Apalagi didalam pengadilan pidana umum dibutuhkan banyak saksi dan Hal ini di

\footnotetext{
${ }^{3}$ Lucille M. Ponte, "Michigan Cyber Court: A Bold Experiment in the Development of the First Public Virtual Courthouse", North Carolina Journal of Law and Technology, Vol 4, Issue 1, January 2002, hlm 58 - 61 PENERAPAN E-COURT DALAM PERKARA... - 12
} 
karenakan setiap penanganan perkara terdapat penggantian biaya bagi saksi yang dihadirkan di Pengadilan Negeri, sesuai dengan Undang-Undang memberi jaminan penggantian biaya kepada saksi/ahli sebagaimana ditegaskan dalam ketentuan Pasal 229 ayat (1) KUHAP yang menyebutkan bahwa: "Saksi atau ahli yang telah hadir memenuhi panggilan dalam rangka memberikan keterangan di semua tingkat pemeriksaan, berhak mendapat penggantian biaya menurut peraturan perundang-undangan yang berlaku". ${ }^{4}$ Selain itu juga, KUHAP tidak memperbolehkan proses peradilan in absentia dalam acara pemeriksaan biasa dan pemeriksaan singkat hal ini dapat di lihat pada Pasal 154 ayat (4) KUHAP. ${ }^{5}$ Asas kehadiran terdakwa ini biasa dikenal dalam tindak pidana khusus seperti pada tindak pidana korupsi dant idnak pidana ekonomi. Asas kehadiran terdakwa ini memiliki sebutan lain yakni ius singular, ius speciale, atau bizonder strafrecht. ${ }^{6}$ Selain itu Asas Kehadiran terdakwa ini berhubungan dengan Asas Pemeriksaan

\footnotetext{
${ }^{4}$ Mulyadi, "Pengetahuan Dasar Hukum Acara Pidana", Bandung, Mandar Maju, 1999, hal. 97.

${ }^{5}$ Aristo M.A. Pangaribuan, Arsa Mufti, dan Ichsan Zikry, "Pengantar Hukum Acara Pidana Di Indonesia", Jakarta, Raja Grafindo, 2017 hlm 245

${ }^{6}$ Lilik Mulyadi, "Hukum Acara Pidana Indonesia: Suatu Tinjauan Khusus Terhadap Surat Dakwaan, Eksepsi,dan Putusan Pengadilan", Bandung, PT. Citra. Aditya Bakti, 2012 hlm 16
}

Hakim yang Langsung dan Lisan. $^{7}$ Tujuannya merupakan upaya penanggulangan kejahatan dengan menggunakan sanksi (hukum) pidana merupakan cara yang paling tua, tegas Prof. Dr. Barda Nawawi Arief, SH, setua peradaban manusia itu sendiri. ${ }^{8}$

Untuk mengisi kekosongan hukum tersebut, penulis merumuskan agar hukum progresif digunakan untuk dijadikan dasar pelaksanaan e-court pada perkara pidana umum. Hukum progresif sendiri lahir dari pemikiran Profesor Satjipto Rahardjo, awal mula pemikiran beliau adalah rasa kekecewaan beliau atas kedangkalan berpikir terhadap ilmu hukum itu sendiri. ${ }^{9}$ Selain itu hukum progresif sendiri merupakan kritik atas mazhab hukum positivisme yang terlalu memfokuskan diri kepada bunyi undang-undang melebihi manfaat hukum itu sendiri. Hal ini dikarenakan pelaksanaan perkara pidana secara online sangatlah mendesak, tanpa adanya pengadilan maka akses menuju keadilan akan terhambat dan ratusan orang tidak bisa mencapai keadilan. Tulisan ini diarahkan untuk mengkaji bagaimanakah

\footnotetext{
${ }^{7}$ Andi Hamzah, "H ukum Acara P idana", Jakarta, Sinar Grafika, 2009 hlm 25

${ }^{8}$ Barda Nawawi Arief . "Beberapa Aspek Kebijakan Penegakan \& Pengembangan Hukum Pidana", Cetakan ke 1. Jakarta, PT. Citra Aditya Bakti. 1998, Hal. 39.

${ }^{9}$ Hans Kelsen, "E ssey in Legal and Moral Philosophy", diterjemahkan ke dalam bahasa Indonesia dengan judul "Hukum dan Logika" oleh B. Arief Sidharta, cet. Ke 4, Bandung: Alumni, 2011, hlm. 27.
} 
pengaturan $e$-court di Indonesia dan cara hukum progresif mengisi kekosongan hukum mengenai e-court dalam perkara pidana umum.

\section{B. Pembahasan}

\section{a. Pengaturan $E$-court di Indonesia}

Di Indonesia, yang menjadi dasar hukum e-court adalah Peraturan Mahkamah Agung Nomor 3 Tahun 2018 menjadi Peraturan Mahkamah Agung Nomor 1 Tahun 2019 yang menambah satu fitur baru bernama E-Litigation. Pelaksanaan $e$ court di beberapa Pengadilan Negeri secara umum sudah dapat berkontribusi dalam mewujudkan efisiensi dan efektifitas dalam peradilan. Hal ini sesuai dengan Pasal 2 Perma No.1 Tahun 2019 yang menyatakan bahwa e-court dilaksanakan dalam rangka terwujudnya tertib penanganan perkara yang profesional, transparan, akuntabel, efektif, efesien, dan modern. Hal ini sesuai dengan peradilan yang sederhana, cepat, dan biaya ringan. Asas ini tegas disebutkan dalam Pasal 2 ayat (4) UU No. 48 Tahun 2009 tentang Kekuasaan Kehakiman. Namun sayangnya menurut pasal 3 Perma No.1 Tahun 2019, yang dibolehkan beracara melalui acara $e$ court terbatas pada perkara Perdata umum, Perdata Agama, tata usaha militer dan tata usaha negara. Dengan begitu, maka perkara pidana umum tidak bisa diajukan melalui e-court, namun dikarenakan adanya pandemi virus korona maka perkara pidana mau tidak mau dilakukan dengan e-court, hal ini merupakan sebuah terobosan untuk menjadikan proses pemeriksaan perkara pidana umum kedalam $e$-court.

Selanjutnya para advokat yang ingin mendaftarkan diri pada sistem e-court haruslah mendaftarkan diri dengan melengkapi beberapa dokumen yang diperlukan seperti: Kartu Tanda Penduduk, Kartu Anggota Advokat, dan Berita Acara sumpah advokat oleh pengadilan tinggi. Perma ini sangat menjunjung efisiensi. Efisiensi yang dimaksud adalah Mempermudah proses pendaftaran (e-filing) dan pembayaran perkara (e-payment). Hal ini dikarena dengan adanya fitur e-filing dan epayment maka para pihak yang beperkara di pengadilan dapat dengan mudah mendaftarkan perkara di domisilinya masing-masing tanpa perlu keluar rumah dan pengantri di pengadilan. Sedangkan dengan adanya e-payment maka para pihak yang bersengketa dapat membayar perkara dengan aplikasi gadget sehingga tidak perlu repot repot mengantri di ATM. Keuntungan yang kedua adalah terkait dengan pengarsipan, dokumen mengenai sebuah perkara dapat disimpan secara elektronik sehingga mudah diakses 
dan tidak mudah rusak. Meskipun sudah terlaksana dengan baik, namun sejauh ini barulah sebatas pada fitur e-filing, $e$ SKUM dan e-payment. Sedangkan untuk fitur e-summons dan e-litigation belum dapat terlaksana dikarena adanya keengganan dari para pihak untuk dipanggil dan beracara di pengadilan secara elektronik. Kendala e-summons sendiri adalah keengganan dari kedua belah pihak yang bersengketa.

Tanpa adanya persetujuan dari para pihak untuk dipanggil secara elektronik maka $e$ summons tidak akan dapat untuk dilaksanakan. Begitu juga dengan $e$ litigation tanpa adanya consent atau persetujuan dari pihak untuk bersidang secara elektronik tentu penyampaian jawaban, replik, duplik, pemeriksaan saksi atau ahli secara elektronik hingga pembacaan putusan secara elektronik sebagai bagian dari e-litigation tentu tidak dapat dilaksanakan, kecuali dalam perkara TUN. Hal ini sejalan dengan Pasal 15 Ayat (1) Huruf b jo. Pasal 20 Ayat (1) PERMA No. 1 Tahun 2019 yang memang secara limitatif mempersyaratkan persetujuan para pihak dalam penggunaan e-summons dan e-litigation. Dalam praktiknya para pihak akan diminta mengisi dan menandatangani formulir "Persetujuan Para Pihak Untuk Beracara Secara Elektronik". Keengganan para pihak untuk dipanggil dan beracara secara elektroni diakibatkan oleh masih adanya ketidakpahaman yang mengakibatkan pengguna peradilan menjadi khawatir ketika panggilan sidang ataupun dokumen perkara tidak sampai karena semuanya tidak berbentuk fisik melainkan berbasis elektronik atau online. Sebenarnya elitigation sudah diatur secara tersurat pada Perma No.1 Tahun 2019 namun secara implimentasinya, ada hambatan dari para pihak yang bersengketa sehingga keduabelah pihak lebih setuju untuk menjalankan proses pengadilan secara konvensional.

Dalam Bab V dijelas pasal pasal yang menjelaskan mengenai persidangan secara elektronik, pertama-tama hakim anggota atau hakim ketua menjelaskan tentang hak dan kewajiban para pihak terkait persidangan secara online. Selanjutnya persidangan secara online dilakukan mediasi selesai, adapun untuk perkara yang tidak memerlukan mediasi maka persidangan secara online bisa langsung dilakukan. Pada e-litigasi ini acara persidangan secara Elektronik oleh para pihak dimulai dari acara jawaban, replik, duplik dan kesimpulan. Untuk jadwal persidangan sudah terintegrasi dengan tundaan sidang di SIPP. Dokumen dikirim setelah terdapat tundaan sidang dan ditutup sesuai jadwal sidang. Untuk mekanisme kontrol (menerima, memeriksa, meneruskan) dari semua dokumen yang 
diupload para pihak dilakukan oleh majelis hakim/hakim yang berarti ketika kedua belah pihak mengirimkan dokumen dan selama belum diverifikasi oleh majelis/hakim kedua belah pihak tidak dapat melihat atau mendownload dokumen yang dikirim oleh pihak lawan.

Namun, Perma ini mempunyai beberapa kelemahan, seperti pengaturan mengenai Verifikasi/pencocokan bukti surat dengan dokumen aslinya. Pasal 1888 KUHPerdata yang menyebutkan: "Kekuatan pembuktian suatu bukti tulisan adalah pada akta aslinya." Kaidah hukum putusan Mahkamah Agung Republik Indonesia No. 112 K/Pdt/1996 tanggal 17 September 1998, sebagai berikut: "Fotocopy suatu surat diserahkan oleh salah satu pihak ke persidangan pengadilan perdata untuk digunakan sebagai "alat bukti surat". Ternyata fotocopy surat tersebut tanpa disertai "surat aslinya" untuk disesuaikan dengan surat aslinya tersebut atau tanpa dikuatkan oleh keterangan saksi dan alat bukti lainnya. Dalam keadaan yang demikian ini maka fotocopy surat tersebut menurut hukum pembuktian acara perdata tidak dapat digunakan sebagai alat bukti yang sah dalam persidangan pengadlian."

Selain itu, dokumen dokumen yang berhubungan dengan berkaitan dengan pengadilan dapat ditransmisikan dengan cepat merupakan keuntungan dari $e$-court. ${ }^{10}$ Selain itu juga, untuk agar pemberlakuan $e$ court secara luas, maka tidak perlu persetujuan para pihak untuk menyetujui pelaksanaan persidangan secara e-court. Seharusnya didalam rumusan peraturan yang akan mendatang cukup ketua pengadilan Negeri/Tinggi yang menetapkan mana kasus yang dapat dilakukan secara $e$ court

\section{b.Cara Hukum Progresif Mengisi} Kekosongan Hukum Mengenai E-Court dalam Perkara Pidana Umum

Ketiadaan hukum acara yang melandasi persidangan perkara pidana secara online, tidak serta merta membuat pelaksanaannya ditiadakan. Kekosongan hukum ini haruslah diatasi dengan cepat, karena jika tidak maka akan membuat ketidakpastian bagi para pencari keadilan. Ketika hukum acara tiada, maka aspek-aspek keadilan lainnya yang notabene menjadi prasyarat tercapainya keadilan prosedural tidak dapat dipenuhi. Salah satunya berkenaan dengan akses kepada keadilan (access to justice) yang menjadi masalah utama dalam bagian ini. Konsep access to justice memang lebih dikenal sebagai wahana yang menitik beratkan pada pemenuhan keadilan bagi

\footnotetext{
${ }^{10}$ Paustinus Siburian, “Arbitrase Online Alternatif Penyelesaian Sengketa Perdagangan Secara Elektronik", Djambatan, Jakarta, 2004, hlm. 41.
} 
masyarakat miskin dan termarginalisasi.

Hal ini dikarenakan Penegak hukum dalam hal ini Polisi, Jaksa, Hakim dan Lawyer akan selalu menggunakan pasal-pasal undang-undang sebagai senjata utama dalam menangani suatu perkara, karena "pasal undang-undang adalah sesuatu yang logis, rasional dan demi kepastian hukum."11

Namun Apabila diletakkan dalam perspektif yang lebih luas, konsep ini juga dapat dimaknai sebagai wadah bagi siapapun untuk mendapatkan bantuan hukum yang layak, demi membentuk proses peradilan yang berkeadilan. Untuk memberi ruang bagi pemenuhan access to justice, aturan main yang baku dan terang harus ditetapkan terlebih dahulu. ${ }^{12}$ Aturan tersebut diantaranya harus menjabarkan bagaimana gugatan diajukan, bagaimana termohon dapat membela diri, atau bagaimana advokat dapat terlibat di dalamnya, baik di sisi pemohon maupun termohon. Apabila aturan main tidak ada, maka siapa saja pihak yang dapat berpartisipasi dan bagaimana mereka dapat berperan menjadi kabur. Namun

\footnotetext{
${ }^{11}$ Soetandyo Wignyosoebroto,2008, "H ukum dalam Masyarakat, Perkembangan dan Masalah, Sebuah Pengantar keArah Kajian Sosiologi Hukum", Bayumedia Publishing, Malang, hlm. 50.

12 Arasy Pradana A Azis, "Kekosongan Hukum Acara Dan Krisis Access to justice Dalam KasusKasus Pemberhentian Kepala Daerah/Wakil Kepala Daerah Di Indonesia", Jurnal Hukum \& Pembangunan 49 No. 1 2019, Hlm.6
}

mengingat kemendesakannya pengadilan. Maka mau tidak mau lembaga pengadilan harus menjalankan sidang tanpa ada aturan baku terlebih dahulu. Pada umunya masyarakat para pencari keadilan menginginkan dan membutuhkan agar proses penyelesaian perkara dilakukan dengan cepat dan formalistis atau informal procedure and can beput into motion quiqly. ${ }^{13}$

Untuk mengatasi hal tersebut, sudah saatnya lembaga peradilan menggunakan metode dari mazhab hukum progresif. Definisi hukum progresif mungkin susah untuk ditemukan, tetapi menurut Mantan Ketua Mahkamah Konstitusi, Moh. Mahfud MD yang juga mengakui hukum progresif sulit dibuat per definisi. Bagi seorang hakim, hukum progresif adalah hukum yang bertumpu pada keyakinan hakim, dimana hakim tidak terbelenggu pada rumusan UU. Seorang hakim berani mencari dan memberikan keadilan bahkan ketika harus melanggar UU karena UU tidak selamanya bersifat adil. ${ }^{14}$

Hukum progresif memiliki karakteristik antara lain sebagai berikut. ${ }^{15}$ 1) Bertujuan untuk kesejahteraan dan kebahagiaan

\footnotetext{
${ }^{13}$ Saifullah, "Refleksi Sosiologis Hukum", Bandung, Reflika Aditama, 2007, hal. 3.

14 Ahmad Rifai, "Penemuan Hukum Oleh Hakim D alam Perspektif H ukum P rogresif" , Jakarta, Sinar Grafika, 2010, hlm. 6

${ }^{15}$ Satjipto Rahardjo, "Hukum Progresif yang M embebaskan", Jurnal Hukum Progresif, Vol.1/No.1/April 2005, PDIH UNDIP, Semarang,hlm.35-36.
} 
manusia dan oleh karenanya memandang hukum selalu dalam proses menjadi (law in the making); 2) Peka terhadap perubahan yang terjadi di masyarakar, baik local, nasional maupun global; 3) Menolak status quo manakala menimbulkan dekadensi suasana korup dan sangat merugikan kepentingan rakyat, sehingga menimbulkan perlawanan dan pemberontakan yang berujung pada penafsiran progresif terhadap hukum.

Salah satu penerapan hukum progresif adalah melalui penemuan hokum. Metode penemuan hukum itu sendiri bukan metode ilmu hukum maupun teori hukum sebab metode penemuan hukum hanya dapat digunakan dalam praktek hukum terutama oleh hakim dalam memeriksa dan memutus perkara. Menurut Bernard L.Tanya hukum progresif adalah hukum pro kadilan dan pro rakyat. ${ }^{16}$ Artinya dalam berhukum para pelaku hukum dituntut mengedepankan kejujuran dan ketulusan dalam penegakan hukum. Mereka harus mempunyai empati dan kepedulian kepada penderitaan dan dialami oleh rakyat. Kepentingan rakyat dalam hal ini kesejahteraan harus menjadi orientasi dan tujuan akhir dalam penyelenggaran hukum. Oleh karena itu

\footnotetext{
${ }^{16}$ Bernard L.Tanya,dkk, "Teori Hukum Strategi Tertib Manusia Lintas Ruang dan Generasi", Yogyakarta Genta Publishing, 2010, hlm.212
}

metode penemuan hukum bersifat praktikal yaitu diarahkan pada suatu peristiwa yang bersifat khusus, konkrit, dan individual. ${ }^{17}$ Hukum tinggal diimplementasikan sesuai teksnya, persoalan peri-kemanusiaan manusia yang menjalankan hukum, tak punya ruangnya. Kalau begini, sejatinya tidak perlu manusia yang menyelenggarakan hukum, robot atau mesin juga bisa, karena 'human' sedang tidak lagi bisa memasukkan 'humanity' nya.Dalam hal ini hukum itu kemudian berada di wilayah yang esoteris, terisolasi dan terasing dari masyarakat awam. ${ }^{18}$

Seperti Pasal 2 ayat 4 Undang-undang Nomor 48 Tahun 2009 tentang Kekuasaan Kehakiman yang menyatakan bahwa: "Peradilan dilakukan dengan sederhana, cepat, dan biaya ringan". "Sederhana" di sini artinya adalah, pemeriksaan dan penyelesaian perkara dilakukan dengan cara efisien dan efektif. "Biaya ringan" artinya adalah biaya perkara yang dapat di jangkau oleh masyarakat banyak. ${ }^{19}$

Sudah seharusnya para penegak hukum terlepas dari belenggu mazhab positivisme yang mengandalkan bunyi undang undang. Positivisme merupakan paham yang

\footnotetext{
${ }^{17}$ Shidarta, "Peragaan Pola Penalaran Hukum Dalam Kajian Putusan Kasus Tanah Adat" , Jurnal Yudisial, Vol. III No. 3, Desember 2010, Komisi Yudisial RI, Jakarta, hlm. 208.

${ }^{18}$ Satjipto Rahardjo, "Hukum dan Perilaku: Hidup Baik Adalah Dasar Hukum yang Baik" ,2009, Jakarta, Penerbit Kompas, Hlm.8

${ }^{19}$ Bakri, M., "P engantar H ukum Indonesia", Malang, UB Press, 2011, hal. 148
} 
menuntut kebenaran lepas dari segala prasangka metafisis, jika diterapkan dalam bidang hukum maka aliran filsafat ini menginginkan hukumagar tidak lagi dikonsepsikan sebagai asas moral metayuridis yang abstrak tentang hakikat keadilan, melainkan ius yang telah mengalami positivisasi sebagai lex. $^{20}$ Dalam paradigma positivisme hukum, undang-undang atau keseluruhan peraturan perundang-undangan dipikirkan sebagai sesuatu yang memuat hukum secara lengkap sehingga tugas hakim tinggal menerapkan ketentuan undangundang secara mekanis dan linear untuk menyelesaikan permasalahan masyarakat, sesuai bunyi undang-undang. Paradigma ini menempatkan hakim sebagai corong undang-undang, tidak memberi ruang kepada hakim sebagai subyek yang kreatif. $^{21}$

Permasalahan penerapan hukum progresif secara keseluruhan Di Indonesia adalah bahwa penegak hukum terlalu saklek/kaku dalam menafsirkan kalimat kalimat yang dirumuskan pada pasal-pasal yang terdapat dalam peraturan perundang-undangan. Bukan rahasia lagi bahwa para penegak hukum tidak berani melakukan metode

\footnotetext{
${ }^{20}$ Otje Salman \& Anton F. Susanto." Teori Hukum: Mengingat, Mengumpulkan, dan Membuka Kembali", Bandung, Refika Aditama, 2005, hlm. 79-80.

${ }^{21}$ Widodo Dwi Putro. "Kritik Terhadap Paradigma Positivisme Hukum", Yogyakarta, Genta Publishing, 2010, hlm. 1-2.
}

hukum progresif dikarenakan sudah membudayanya kebiasaan positivisme di lingkup peradilan, sehingga jika ada pihak yang menggunaka metode hukum progresif maka pihak tersebut dapat dengan mudah dikalahkan atau dipertanyakan. Demikian pula keadilan, keadilan bukan verifikasi saklek atas maksud umum kalimat implikatif yang dirumuskan dalam pasalpasal Undang-Undang. Keadilan bukan tugas rutin mengetuk palu digedung pengadilan. Keadilan juga tidak butuh hakim pemalas dan tumpul rasa kemanusiaannya. Yang dibutuhkan bahwasanya keadilan adalah keberanian tafsir atas Undang-Undang untuk mengangkat harkat dan martabat manusia Indonesia. Sehingga keadilan hanya diasumsikan kepada rutinitas polisi, jaksa, dan hakim sebagai mata pencaharian didalam sebuah gedung. Sebab, bagi aparat, menjadi PNS atau polisi bertujuan untuk bekerja. Karena itu, hukum hanya bagian dari tumpukan file dimeja penegak hukum yang harus diselesaikan. Isu umum yang terjadi di Indonesia, penuntasan masalah hukum mengacu pada prinsip pekerjaan. Dalam rangka mengisi beberapa kekosongan hukum dalam menyelenggarakan e-court (persidangan online) diperlukan penalaran hukum bagi yang baik bagi penegak hukum. Sekalipun eksponen Critical Legal Studies seperti Duncan Kennedy selalu menyangsikan 
kekhasan dari penalaran hukum tersebut. Kennedy pernah berujar, "Teachers teach nonsense when they persuade students that legal reasoning is distinct, as a method for reaching correct results, from ethical or political discourse in general. There is never a 'correct legal solution' that is other than the correct ethical or political solution to the legal problem." 22

Peter Wahlgren dari Stockholm Institute for Scandianvian Law dalam artikelnya tentang Legal Reasoning, menyatakan bahwa penalaran hukum merupakan istilah yang dipakai untuk melabeli banyak aktivitas dalam bidang hukum: proses mental yang bekerja dalam pengambilan keputusan hukum; identifikasi kasus, interpretasi, atau mengevaluasi fakta hukum; pilihan aturan hukum, dan penerapan hukum dalam kasus-kasus konkret; penyusunan sebuah pertimbangan, argumen, opini atau pendapat hukum. Tetapi semua aktivitas ini didasarkan para cara bernalar yang tepat (logika). Dalam perspektif tujuan hukum, penalaran hukum yang ideal ialah penalaran hukum yang mampu mewujudkan ketiga terminology hukum yaitu keadilan, kepastian hukum,dan kemanfaatan secara bersama-

\footnotetext{
${ }^{22}$ A. Sukris Sarmadi, "Membebaskan Positivism Hukum ke Ranah Hukum Progresif (Studi Pembacaan Teks Hukum Bagi Penegak Hukum)", Jurnal Dinamika Hukum, Vol. 12 No. 2, Mei 2012, Purwokerto: Fakultas Hukum UNSOED, hlm. 333.
}

sama dan juga secara berimbang. ${ }^{23}$ Cara berfikir dan penalaran hakim yang bersifat linier merupakan cerminan dari kelsenian (Hans Kelsen), yang menampilkan karakter logical yang kuat, bahan hukum tidak lain adalah pengolahan logika bahanbahan hukum positif, sedangkan bahan hukum positif adalah undang-undang dan sumber hukum positif lainnya. ${ }^{24}$

\section{KESIMPULAN}

Berdasarkan pembahasan atas permasalahan yang dikaji, maka dapat diambil kesimpulan sebagai berikut.

1. Di Indonesia, dasar hukum pelaksanaan $e$ court adalah Perma Nomor 1 Tahun 2019. Pengadilan pidana umum secara online atau menggunakan sistem e-court belum diatur oleh Perma Nomor. 1 Tahun 2019. Perma juga belum mengakomodasi beberapa hal seperti verifikasi/pencocokan bukti surat dengan dokumen aslinya.

2. Walaupun pelaksanaan e-court pada pidana umum belum memiliki dasar hukum tetapi dalam konteks hokum progresif hal itu harus tetap dilaksanakan melalui penalaran hukum. Hal ini

\footnotetext{
${ }^{23}$ Setiawan, A., 2017, "Penalaran Hukum Yang Mampu Mewujudkan Tujuan Hukum Secara Proporsional", dalam Jurnal Hukum Mimbar Justitia, Vol. 3, No. 2. Hlm.13

${ }^{24}$ Widodo, J. P. 2011. "Penalaran Hukum Dalam Proses Mengadili Perkara Pidana Dalam Kerangka Kebebasan Hakim”. Jurnal Pranata Hukum Vol. 6, No. 2, hlm. 136.
} 
dilakukan dalam rangka menjamin access to justice bagi pencari keadilan.

\section{DAFTAR PUSTAKA}

Buku

Achmad Rifai. 2010. Penemuan Hukum Oleh Hakim Dalam Perspektif Hukum Progresif. Jakarta: Sinar Grafika.

Andi Hamzah. 2009. Hukum Acara Pidana. Jakarta: Sinar Grafika.

Aristo M.A. Pangaribuan 2017. Pengantar Hukum Acara Pidana Di Indonesia. Jakarta: Raja Grafindo.

B. Arief. Sidharta 2011. Hukum dan Logika. Bandung: Alumni.

Barda Nawawi Arief. 1998. Beberapa Aspek Kebijakan Penegakan \& Pengembangan Hukum Pidana. Jakarta: PT Citra Aditya Bakti.

Otje Salman. 2005. Teori Hukum: Mengingat, Mengumpulkan, dan Membuka Kembali. Bandung: Refika Aditama.

Paustinus Siburian. 2004. Arbitrase Online Alternatif Penyelesaian Sengketa Perdagangan Secara Elektronik. Jakarta: Djambatan.

Peter Mahmud Marzuki. 2017. Penelitian Hukum: Edisi Revisi. Jakarta: Prenada Media.

Lilik Mulyadi. 2012. Hukum Acara Pidana Indonesia: Suatu Tinjauan Khusus Terhadap Surat Dakwaan, Eksepsi,dan Putusan Pengadilan. Bandung: PT Citra Aditya Bakti.
M. Bakri 2011. Pengantar Hukum Indonesia. Malang: UB Press.

Mulyadi. 1999. Pengetahuan Dasar Hukum Acara Pidana. Bandung: Mandar Maju.

Saifullah. 2007. Refleksi Sosiologis Hukum. Bandung: Reflika Aditama.

Satjipto Rahardjo. 2009. Hukum dan Perilaku: Hidup Baik Adalah Dasar Hukum yang Baik. Jakarta: Kompas.

Soetandyo Wignyosoebroto. 2008. Hukum dalam Masyarakat, Perkembangan dan Masalah, Sebuah Pengantar keArah Kajian Sosiologi Hukum. Malang: Bayumedia Publishing.

Tanya, Bernard L. 2010. Teori Hukum Strategi Tertib Manusia Lintas Ruang dan Generasi. Yogyakarta: Genta Publishing.

Widodo Dwi Putro. 2010. Kritik Terhadap Paradigma Positivisme Hukum. Yogyakarta: Genta Publishing.

Jurnal

A. Setiawan 2017. "Penalaran Hukum Yang Mampu Mewujudkan Tujuan Hukum Secara Proporsional." Jurnal Hukum Mimbar Justitia 13.

A. Sukris Sarmadi 2012. "Membebaskan Positivism Hukum ke Ranah Hukum Progresif (Studi Pembacaan Teks Hukum Bagi Penegak Hukum)." Jurnal Dinamika Hukum 333

Arasy Pradana Aziz. 2009. "Kekosongan Hukum Acara Dan Krisis Access to justice Dalam Kasus-Kasus Pemberhentian Kepala Daerah/Wakil Kepala Daerah Di Indonesia." Jurnal Hukum \& Pembangunan 6.

Carrington, Paul D. 1990. "Virtual Civil Litigation : A Visit to John Bunyan's 
Celestial City." Columbia Law Review, Vol. 98 1516-1517.

J. P. Widodo 2011. "Penalaran Hukum Dalam Proses Mengadili Perkara Pidana Dalam Kerangka Kebebasan Hakim." Jurnal Pranata Hukum 136.

Lederer, Fredric I. 1999. "The Road to the Virtual Courtroom? A Consideration of Today's - and Tomorrow's- High Technology Courtrooms, Virginia." William and Mary Law School Scholarship Repository 800-801.

Ponte, Lucille M. 2002. "Michigan Cyber Court: A Bold Experiment in the Development of the First Public Virtual Courthouse." North Carolina Journal of Law and Technology, 58-61.
Satjipto Rahardjo. 2005. "Hukum Progresif yang Membebaskan." Jurnal Hukum Prograsif 35-36.

Shidarta. 2010. "Peragaan Pola Penalaran Hukum Dalam Kajian Putusan Kasus Tanah Adat." Jurnal Yudisial 208. 